\title{
Leadership Coaching 2.0: Improving the Marriage between Leadership and Coaching
}

\author{
Ken Otter \\ California, USA
}

\begin{abstract}
This paper posits that in order for leadership coaching to realize its potential as a method for leadership development and to mature as a coaching specialty, a more robust engagement with the field of leadership and leadership development is needed. It describes the author's journey of exploring the link between his knowledge of leadership and of coaching to enhance his own practice in leadership coaching. This description serves to highlight areas in need of attention in the present state of leadership coaching as it is presented in the literature. It concludes by positing that leadership coaching education programs are ideal locales to address those needs, specifically by convening a shared inquiry among practitioners, scholars and educators on identifying the important links between the fields of leadership and leadership coaching and helping coaches incorporate them as an integral part of their understanding and practice of leadership coaching.
\end{abstract}

Keywords: leadership coaching, executive coaching, coach education, leadership development

In this paper, I posit that, because leadership coaching is increasingly viewed as a viable method for leadership development and continues to grow as a coaching specialty (Ely, Boyce, Nelson, Zaccaro, Hernez-Broome \& Whyman, 2010; Goldsmith, 2012; Maltbia, Marsick \& Ghosh, 2014; Passmore, 2015), it would benefit from a more robust engagement with the field of leadership and leadership development (Korotov, 2016; Otter, 2014). I argue that such an engagement would contribute to the understanding, practice and development of leadership coaching skills. Given that the fields of leadership and leadership development are made up of many varied and contested features - concepts, definitions, theories, and research studies (Harter, 2006; Hunt, 1991; Heifetz \& Sindler, 2005; Rost, 1993) - such an engagement is no easy task, yet it remains something important to pursue. I also argue in this paper that the challenging and necessary work to advance this engagement would benefit greatly by leadership coaching education programs, both inside and outside of academia, taking up the responsibility. 


\section{The Evolution of My Involvement with Leadership Coaching}

After more than a decade as a family counselor and an educator, in the late 1990s I began teaching leadership in both academic and non-academic programs, during the time I was completing my doctoral studies in adult learning. My teaching drew upon both my experience and education in human development and learning and my practical experience in leadership.

In 2002, I was hired to help design and teach in a graduate program in leadership for working professionals in the San Francisco Bay Area. I quickly saw that my own experience in leadership was an insufficient basis for working with people with experience, needs, and contexts that differed from mine. To expand my knowledge, and to understand how to serve my students and clients better, I shifted my dissertation focus to researching leadership development. This shift exposed me to a wider range of perspectives, research, and theory on leadership and leadership development. By the time I completed my doctoral research, I had been working in the field of leadership education and development for well over a decade.

I made two critical observations during this time: first, that a single individual assumes different leadership roles in the course of their job, and second, that individual and team coaching are valuable as an integral part of leadership development.

With regard to the first observation about leadership roles, I saw that my students and clients, all working professionals and many of them managers at various levels in their organizations in the public, profit or not-for-profit sector, were navigating a complexity of roles and responsibilities and needing to practice leadership that was commensurate with this complexity. Those in law enforcement provide an excellent case in point.

In police work, officers are required to practice different forms or approaches to leadership, depending on the context. For law enforcement professionals, there are at least three forms of leadership in play. In emergency situations, effective command leadership is required. As a manager within the agency, a more leader-centric and authority-based leadership is expected. As part of a stakeholder group in a city, such as a member of a task force or someone developing standards and policies in police work, where the individual may not have role authority, a more adaptive or collaborative leadership approach may be warranted. 
Not only are there different leadership theories and research studies associated with each role, each requires a different mindset and differing capacities and skills. For example, the type of communications skills needed during a citywide protest is different than the type needed in a working task force on how to improve policing crowds in such protests. As someone charged to develop leadership competency, when sought by police officers wanting to improve their various forms of leadership, I found my theoretical knowledge of leadership and leadership development helpful in identifying and developing in my clients the different skills needed to enact leadership in these dynamic and varied contexts.

Second, I saw the value of individual and team coaching, as either adjunct to training and education programs (Allen \& Roberts, 2011) or a primary pathway (Lee, 2017; Stroul \& Wahl, 2013). Identified in the literature as a viable strategy for leadership development (Allen \& Roberts, 2011; Day, 2000, 2012), coaching as a useful component of leadership was evident to me in the experiences of students and clients in the various leadership development programs in which I participated. Moreover, as the director and a faculty member in the leadership studies department at my university, I found receiving coaching myself to be helpful in my own practice of leadership as well.

Because of these experiences, examining coaching as a viable path for leadership development became a new academic and practice focus for me.

\section{Three Directions and Four Questions}

Just as my academic study of leadership and leadership development served my educational and facilitation practice, an academic study of coaching promised to serve my coaching and coach education practice. This quest has taken on four distinct but interrelated directions, all of which inform this paper in significant ways.

The first direction I took was to read books and articles on leadership coaching in both trade and scholarly publications. Second, although my experience in counseling, education and leadership provided me with some skills in coaching, to develop my practical and theoretical knowledge as I aspired to meant that I would need to complete a formal education in coaching. Therefore, I completed a certificate program in Executive and Organizational Coaching. Along with enhancing my understanding and competency in coaching, this study led me to a lot of questions about what leadership coaching is and what it could be. 
This experience ignited my third direction, to embark on a research project to understand more about what leadership coaching is and how to develop it as a viable coaching specialty. This third direction has catalyzed this paper and its focus. Yet, as the reader will quickly see, the other two directions - reading and study - are implicated in this paper as well.

Wanting to find out how coaching can best help people working in dynamic, varied and complex contexts, like those in law enforcement, I again turned to the literature. As a fourth direction, I embarked on a systematic review of the literature in leadership coaching and wrote about my findings in a conference paper presented at the First Annual Columbia Coaching Conference in 2014 (Otter, 2014).

In my review of the leadership coaching literature, I discovered three significant issues. First, as mentioned, leadership coaching is increasingly being used as an adjunct to education and training programs in leadership, or as a stand-alone method for leadership development (Ely, Boyce, Nelson, Zaccaro, Hernez-Broome \& Whyman, 2010; Goldsmith, 2012; Maltbia, Marsick \& Ghosh, 2014; Passmore, 2015), with, however, little research on its efficacy. Second, leadership coaching is largely understood to be about coaching people in designated leader roles and positions; as such, it is often used interchangeably with executive coaching (Korotov, 2016; Maltbia, et al., 2014). I found little in the literature on how to provide coaching for people who also practice leadership beyond their organizational role or without a formal role, and in contexts of collaboration. Third, with few exceptions (Anderson, 2013; Korotov, 2016), there is relatively little engagement with the scholarly field of leadership and leadership development in the coaching literature (Beattie, Kim, Hagen, Egan, Ellinger\& Hamlin, 2014; Ely et al., 2010). All three of these discoveries propelled me to learn more about how leadership coaching could expand its scope and effectiveness to serve as a useful pathway for leadership development in varied, dynamic and complex contexts.

From these discoveries came four key questions. The first was, How might I better understand what leadership coaching is, how to be effective in it, and how to contribute to its development as a specialty? In response, I began researching the current state of leadership coaching described both in the literature and in the experience and philosophy of practitioners. I discovered that there were relatively few empirical studies on the effectiveness of leadership coaching in clients, how it gets developed in practitioners, and what role practical and theoretical leadership knowledge plays and should play in leadership coaching. 
Although scientific research is not the only means to develop leadership coaching as a viable method for leadership development, in my experience as a counselor and an educator, it offers much to the practical art of leadership. In fact, in the maturation of other helping professions, such as medicine, attention to developing a scientific knowledge base through empirical research and theory development is key to improving its practice (Noordegraaf, 2007). For professional coaching to match its credibility with its growing popularity, I join the voices of many who advocate a more scholarly agenda in studying its practice (Korotov, 2016; Maltbia et al., 2014).

The second question that surfaced in my preliminary literature review was this: Is leadership coaching just another name for executive coaching, making it simply about coaching designated leaders in formal roles and positions? In my review of the literature in leadership coaching, the terms leadership coaching and executive coaching appeared to be conflated and used interchangeably. For example, Maltbia et al. (2014) define executive coaching as "a developmental process that builds a leader's capabilities to achieve professional and organizational goals" (p. 165). Morgan, Harkins and Goldsmith (2005) define executive coaching as "a precision tool for optimizing the abilities of leaders" (p. 23).

I found that this type of leader-centric understanding of leadership predominates in the literature of leadership coaching. Leadership coaching is commonly described as a personalized, customized, or individualized process to support and facilitate leadership development of leaders in organizations (Goldsmith, 2012; Kets, de Vries, 2006). Ely et al. (2010) define leadership coaching as "a relationship between a client and a coach that facilitates the client becoming a more effective leader" (p. 585). Ting (2006) describes it as a process "to help leaders understand themselves more fully so that they can draw on their strengths and use them more effectively and intentionally, improve developmental needs, and develop untested potential" (p. 15). Common to these definitions is the emphasis on individuals already in leadership roles.

Exemplifying this prevailing view in a recent review of the leadership coaching literature, Korotov (2016) comments, "Common sense suggests that leadership development should be about helping people be better leaders" ( $p$. 2). This definition of leadership coaching as supporting people in leader roles and positions runs the risk of conceiving leadership as merely "that which leaders do" (Rost, 1993), rather than a distinct social activity that differs from other related activities, such as managing and governing (Dunoon, 2008; Otter, 2017). 
Decoupling leadership from actions of individual leadership and from managerial activities, and expanding the understanding of leadership beyond the traits and behaviors of individual leaders to leadership as an activity that is a property of a social system, has been a rich vein of research and theorizing in the leadership field for more than two decades (Bolden, Hawkins, Gosling, \& Taylor, 2011; Grint, 2010; Harter, 2006; Hunt, 1991; Kezar, Carducci \& Contreras-McGavin, 2006; Komives, Longerbeam, Mainella, Osteen, Owen, \& Wagner, 2009; Rost, 1993; Uhl-Bien 2006; Uhl-Bien, Maslyn, \& Ospina, 2012). With a few notable exceptions (Courville, 2103; Passmore, 2015), there is surprisingly little of this robust theory present in the leadership coaching literature. For example, there is little discussion about differentiating between leadership as a role or position and leadership as a process or activity (Anderson, 2013; Grint, 2010), nor is there attention to differentiating between leader-centric and relational forms of leadership (Day, 2000; Otter, 2012; UhlBien, 2006).

Developing capacities in leaders and in those preparing to be in leader roles is definitely an important area and deserving of much attention. But so, too, is developing leadership capacities in people when leadership is enacted as an activity or process, when people are not in leader roles and positions but participants in a team or a collective of some kind (Denis et al., 2012; Marion \& Uhl-Bien, 2001). Although some attention is being paid to team leadership (Britton, 2013) the times seem particularly ripe for leadership coaching to give more attention to developing leadership that is plural, shared, and collective.

The following vignette of one of my coaching engagements offers an apt illustration. A director of parks and recreation in a small university town sought leadership coaching to address an area of his job where he felt neither competent nor confident. In contrast to his sense of competence and confidence in leading his department, he struggled when required to engage various stakeholder groups in regular community meetings and planning processes. As the coaching unfolded, he ultimately recognized that the competencies that work well as a manager leading his department were not the ones needed in these community-involved processes. When working with multiple stakeholders with divergent loyalties, needs and interests, it was hard for him to find solid footing. In working with him, I found it helpful to have an understanding of leadership that encompassed a range of forms and expressions, each requiring different capacities and skills.

This understanding resulted in certain lines of inquiry. For example, I asked him how he understood his experience and expectations in practicing 
leadership in each domain, as well as what he thought his strengths and limitations were in each. From there another line of inquiry unfolded around what he thought leadership should look like for him and for others in these community planning processes. This inquiry included exploring the capacities and skills he needed to develop in order to practice leadership in these settings more effectively.

By experimenting with different actions, such as facilitating conversations between people in conflict, staying with ambiguity and uncertainty longer, and helping others develop basic interpersonal and dialogue skills, the client recognized that he needed to bring different leadership understanding and competencies to each of his domains of practice. He also learned that the community planning process work required more preparation and attention from him than the straight managerial leadership role he assumed in his office.

The third question that emerged for me from my review of the leadership coaching literature was this: Assuming more engagement with the field of leadership and leadership development would advance the practice of leadership coaching, how might this need be addressed?

Although leadership coaching is presented in the literature as an organizational intervention to enhance capacity in leadership for individual leaders and leadership teams (Nieminen, Biermeier-Hanson \& Denison, 2013; Korotov, 2016), the literature largely focuses on various theories that make up and inform the coaching process, such as theories of human performance, adult development, psychology, communication, organizational culture, and business (Cox, Bachkirova \& Clutterbuck, 2014). There is surprisingly little engagement with leadership theory (Anderson, 2013; Nieminen et al., 2013; Korotov, 2016). For example, in their evaluation of leadership coaching, Ely et al. (2010) identify leadership coach qualifications to include graduate behavioral science training, business awareness, and, in order to have credibility and expertise, knowledge of or experience in the client's industry. However, there is no mention of knowledge about leadership and leadership development theories.

Among leadership development scholars it is widely recognized that how one defines or understands leadership determines what gets attention in the developmental process (Day, 2000, 2012; Komives, Ritch \& Mengel, 2009).

For example, if leadership is largely an influence relationship among collaborators, as Rost (1993) claims, then one focus of development would be 
to cultivate the relational and social capital in the enterprise so that shared influence can take place. In this way, the working definition of leadership informs leadership development designs and outcomes (Boaden, 2006; Day \& Antonakis, 2010; Otter, 2012). For leadership coaching, Korotov (2016) underscores the importance of grappling with defining "what leadership is (or expected to be), and how it should be manifested" (p. 2). He goes on to describe the multiple and contested definitions of leadership among leadership scholars and practitioners alike. When leadership coaches and leadership coaching researchers do engage the literature in leadership theory, they must contend with this plurality of definitions, compounding the challenge for coaches to integrate the leadership knowledge base with the coaching knowledge base as part of their practice. Perhaps this is one source of practitioner hesitation in engaging the leadership literature. The question then arises: What part of this vast field of knowledge should be included? This is a question I return to a little later on.

Another possible source of coaches' lack of engagement with the research and theories of leadership and leadership development is the view that the preferred knowledge base for leadership coaches is their personal and professional experience as leaders themselves or from working with leaders (Morgan, Harkins \& Goldsmith, 2005). This familiarity could be sufficient if the experience of the coach matches well with the needs of the client and the organization. However, the complex, turbulent and uncertain conditions in which organizations exist seem to require a wider repertoire of leadership constructs, processes and skills, which may include but also may go beyond a leader-centric view of leadership or the necessarily limited experience of the coach (Heifetz, 1994; Jarche, 2014; McGonigill \& Doerffer, 2011).

Furthermore, the proliferation of leadership articles, trainings, and education programs that present a wider band of leadership perspectives and methods results in a diverse repertoire of leadership practices in organizations (Ciporen, 2008; Otter, 2012). For example, thousands of managers have been educated in the adaptive leadership model developed by Ron Heifetz and colleagues at the Kennedy School of Government at Harvard, which presumes that leadership can be enacted from anywhere in the system, not just from those in role authority (Daloz Parks, 2005). Being exposed to this perspective could open up fruitful lines of inquiry for coaching clients, as it did for me in the coaching example described above.

As coaches, we can advance the leadership development of people who might have a different background, perspective, and practice of leadership than 
we do - and who are enacting leadership from both designated leadership and non-leadership positions - if we are exposed to a wider range of leadership perspectives and models. On this point, Passmore (2015) asserts that familiarity with different leadership perspectives can serve as a guiding framework for coaches to provide "a language for developmental conversations and offer [clients] a heuristic to take into the office for their future development and decision making" (p. 13).

Because familiarity with the full repertoire of leadership theories and perspectives is an unrealistic task for leadership coaches, the question then becomes how to evaluate the various theories about leadership in order to develop more leadership literacy in coaches. This leads to my fourth and last set of questions that emerged in reviewing the literature: How do leadership coaches increase their engagement with the field of leadership and leadership development? What knowledge from those fields should we include? Who convenes this conversation, and who should be included?

Certainly, more research into how coaches practice leadership coaching is one avenue to address these questions. Another is convening conversations among practitioners and scholars such as that which took place at the $19^{\text {th }}$ Annual International Leadership Association Conference, in which leadership scholars and coaches engaged in a shared inquiry on the questions of what the fields of leadership and leadership development offer to leadership coaching (Otter, 2017a). One theme that arose is the importance of differentiating between leadership as embedded in the actions of a designated leader or leadership embedded in the activity of a collective or team. The question that followed this discussion was, What difference, if any, does differentiating between assigned leadership and collective or team leadership make in the coaching process?

Such conversations can only go so far in taking up the responsibility to engage the set of questions that have arisen. What is needed is a sustained conversation on these questions, which I believe could take place in leadership coach education programs in both academic and non-academic settings. For example, these programs can help coaches think about and evaluate the range of leadership theories and practices in relationship to the needs and aspirations of their clients, and they can help identify research topics and questions for coaches to pursue. Indeed, according to Maltbia and Page (2013), coaching programs have the responsibility to engage students in "the multidisciplinary body of knowledge regarding professional coaching" and to facilitate critical 
conversations that help coaches think about, theorize, and evaluate coaching models (p. 12).

Such programs would engage leadership coaching education in particular approaches and theories related to professional coaching, as well as increase engagement with the fields of leadership and leadership development and the research that informs them. This exploration should not be limited to academic programs, but should also take place in non-academic coach education programs as well.

\section{Improving the Marriage of Leadership and Coaching in Leadership Coaching}

The purpose of this paper has been to affirm the value of leadership coaching as either adjunct to leadership training and education programs or as a primary pathway in leadership development while arguing that, for leadership coaching to fulfill this promise, it not only needs more empirical research on its efficacy, but it must also expand its view of leadership beyond those that predominate in the literature in leadership coaching today; in addition, it must engage the practical and theoretical knowledge already developed in the field of leadership and leadership development. How can this happen?

Giving more attention to the practical knowledge about leadership in leadership coaching is an important job of leadership coach education programs. Not only can the exploration and evaluation of the knowledge from the field of leadership and leadership development inform leadership coaching through curricula and program development, class conversations, coach supervision and mentorship, but such programs can also convene dialogues at conferences and seminars as well as foster linkages among research, theory and practice toward a more sophisticated understanding of what makes leadership coaching effective, and how best to conceptualize, practice and develop it.

For the first graduate course on leadership I taught 20 years ago, my class description stated, "The practice of leadership invites people to bring forth their unique, authentic and creative gifts in response to the emerging needs of their particular world." This perspective continues to reflect why I work in this field today. Although I have relied heavily on leadership education to support people in their leadership learning, I am increasingly drawn to transfer some of this investment to leadership coaching practice, education, and research. Just as my first course announcement invited graduate students into an exploration of what is possible for learning leadership, I invite coaching practitioners, researchers 
and educators to explore expanding leadership coaching by enhancing understanding of leadership as a whole so that leadership coaching becomes an equally promising pathway in people's varied and diverse leadership learning journeys and the world these journeys benefit.

\section{References}

Allen S. J., \& Roberts, D. C. (2011). Our response to the question: Next steps in clarifying language of leadership learning. Journal of Leadership Studies, 5(2), 65-70. https://doi.org/10.1002/jls.20220

Anderson, V. (2013). A Trojan horse? The implications of managerial coaching for leadership theory, Human Resource Development International, 16(3), 251-266. https://doi.org/10.1080/13678868.2013.771868.

Boaden. R. J. (2006). Leadership development: Does it make a difference? Leadership and Organization Development Journal, 27(1/2), 5-27. https://doi.org/10.1108/01437730610641331.

Beattie, R.S., Kim, S., Hagen, M.S., Egan, T.M., Ellinger, A.D., \& Hamlin, R.G. (2014). Managerial coaching: A review of the empirical literature and development a model to guide future practice. Advances in Developing Human Resources 16:184. https://doi.org/10.1177/1523422313520476

Bolden, R., Hawkins, B., Gosling, J., \& Taylor, S. (2011). Exploring leadership: Individual, organizational, and societal perspectives. New York, NY: Oxford University Press.

Britton, J. J. (2013). From one to many: Best practices for team and group coaching. Mississauga, Ontario: Jossey-Bass.

Ciporen, R. (2008). The role of personally transformative learning in leadership development: A case study examining the transfer of learning from an executive education program. (Doctoral dissertation). Available from ProQuest Dissertations and Theses database. (UMI No. AAT 3327049).

Courville, W. J. (2103). Mapping the terrain: An overview of professional coaching. In C. Wahl, C. Scriber, B. Bloomfield (Eds.), On becoming leadership coach: A holistic approach to coaching excellence (pp. 1344, 2nd edition). New York, NY: Palgrave Macmillan.

Cox, E., Bachkirova, T., \& Clutterbuck, D. (2014). Theoretical traditions and coaching genres: Mapping the territory. Advances in Developing Human Resources, 12(2), 139-160. https://doi.org/10.1177/1523422313520194.

Daloz Parks, S. D. (2005). Leadership can be taught. Boston, MA: Harvard Business School Press. 
Day, D. V. (2000). Leadership development: A review in context. Leadership Quarterly, 11(4), 581-613.

Day, D. V. (2012). The nature of leadership development. In D.V. Day \& J. Antonakis (Eds.), The nature of leadership (pp. 108-140). Thousand Oaks, CA: Sage.

Day, D. V., \& Antonakis, J. (2012). Leadership: past, present, and future. In D. V. Day, \& J. Antonakis (Eds.), The nature of leadership (pp. 256-288, 2nd edition). Thousand Oaks, CA: Sage.

Denis, J. L., Langley, A., \& Sergi, V. (2012). Leadership in the plural. The Academy of Management Annals. https://doi.org/10.1080/19416520.2012.667612

Dunoon, D. (2008). In the leadership mode. Victoria, BC: Trafford Publishing.

Ely, K., Boyce, L. A., Nelson, J. K., Zaccaro, S. J., Hernez-Broome, G. F. \& Whyman, W. (2010). Evaluating leadership coaching: A review and integrated framework. The Leadership Quarterly. 21, 585-599.

Goldsmith, M. (2012). Coaching for behavioral change. In M. Goldsmith, L. S. Lyons. \& S. McArthur (Eds.), Coaching for leadership: Writings from the world's greatest coaches (pp. 3-9, 3rd edition). San Francisco, CA: John Wiley \& Sons, Inc.

Goldsmith, M., Lyons, L.S., \& McArthur, S. (Eds.). (2012). Coaching for leadership (3rd edition). San Francisco, CA: John Wiley \& Sons.

Grint, K. (2010). Leadership: A very short introduction. Oxford, England: Oxford University Press.

Harter, N. (2006). Clearings in the forest: On the study of leadership. West Lafayette, IN: Purdue University Press.

Heifetz, R.A. (1994). Leadership without easy answers. Cambridge, MA: The Belknap Press of Harvard University Press.

Heifetz, R.A., \& Linsky, M. (2002). Leadership on the line. Cambridge, MA: Harvard Business School Press.

Heifetz, R.A., \&, Sinder, R.M. (2005). A theoretical framework for the practice of public leadership. Unpublished manuscript.

Heifetz, R., Grashow, A., \& Linksy, M. (2009). The practice of adaptive leadership. Boston, MA: Harvard Business Press.

Hunt, J. G. (1991). Leadership: A new synthesis. Newbury Park, CA: Sage.

Jarche, H. (2014). Seeking perpetual beta: A guidebook for the networked era. Sackville, New Brunswick, Canada (retrieved from: http://www.jarche.com).

Kets De Vries, M. (2006). The leader on the couch: A clinical approach to changing people and organizations. San Francisco, CA: Jossey Bass. 
Kezar, A.J., Carducci, R., \& Contreras-McGavin, M. (2006). Rethinking the " $L$ " word in higher education: The revolution of research on leadership. ASHE higher education report: 31(6). San Francisco, CA: Jossey-Bass.

Komives, S.R., Lucas, N., \& McHahon T.R. (2007). Exploring leadership. San Francisco, CA: John Wiley \& Sons, Inc.

Korotov, K. (2016). Coaching for leadership development. In T. Bachkirova, G. Spence, \& D. Drake (Eds.). The Sage handbook of coaching, (pp. 139158. 2nd edition). Thousand Oaks, CA: Sage Publications.

Lee, G. (2017). Leadership coaching: From personal insight to organisational performance. London, UK: Kogan Page Publishers.

Maltbia, T. E., \& Page, L. J. (2013). Academic standards for graduate programs in executive and organizational coaching. Graduate School Alliance for Executive Coaching. Retrieved from http://www.gsaec.org/curriculum.html

Maltbia, T.E., Marsick, V.J., \& Ghosh, R. (2014). Executive and organizational coaching: A review of insights drawn from literature to inform HRD practice. Advances in Developing Human Resources 16: 161. https://doi.org/10.1177/1523422313520474.

Marion, R., \& Uhl-Bien, M. (2001). Leadership in complex organizations. The Leadership Quarterly, 12(4), 389-418.

McGonigill, G., \& Doerffer, T. (2011). Leadership and web 2.0: The leadership implications of the evolving web. Gütersloh, Germany: Verlag Bertelsmann-Stiftung.

Morgan, H., Harkins, P. \& Goldsmith, M. (Eds). (2005). The art and practice of leadership coaching: 50 top executive coaches reveal their secrets. Hoboken, NJ: John Wiley \& Sons, Inc.

Nieminen, L. Biermeier-Hanson, B., \& Denison, D. (2013). Aligning leadership and organizational culture: The leader-culture fit framework for coaching organizational leaders. Consulting Psychology Journal: Practice and Research 65(3), 177-198. https://doi.org/10.1037/a0034385.

Noordegraaf, M. (2007). From "pure" to "hybrid" professionalism: Present-day professionalism in ambiguous public domains. Administration \& Society, 39(6), 761-785.

Northhouse, P. G. (2007). Leadership: Theory and practice. Thousand Oaks, CA: Sage.

Otter, K. (2012). What difference does it make? A qualitative inquiry into the longer-term outcomes of a transformative education in relational 
leadership. (Doctoral Dissertation). Available from ProQuest Dissertations and Theses database. (Order No. 3539799).

Otter, K. (2014). Widening the lens of leadership: Enhancing leadership literacy in coaches, a paper presented at the 1st Annual Columbia University Coaching Conference, New York, NY.

Otter, K. (2017). Navigating the terrain of positive organizing: An engagement with values. In R. Koonce, P. Robinson, \& B. Vogel (Eds.) Developing leaders for positive organizing (pp. 357-372). Bingley, England: Emerald.

Otter, K. (2017a). Leadership coaching 2.0: More than another name for executive coaching, a workshop presented at the 19th Annual International Leadership Association. Brussels, Belgium.

Passmore, J. (Ed.). (2015). Leadership coaching: Working with leaders to develop elite performance: London, UK: Kogan Page Publishers.

Ritch, S. W., \& Mengel, T. (2009). Guiding questions: Guidelines for leadership education programs. Journal of leadership education. 8(1), 216-226. Retrieved from http://www.fhsu.edu/jole/issues/JOLE_8_1.pdf.

Rost, J. (1993). Leadership for the twenty-first century. New York, NY: Praeger.

Stroul, N., \& Wahl, C. (2013). On becoming a leadership coach. In C. Wahl, C. Scriber, B. Bloomfield (Eds.), On becoming leadership coach: A holistic approach to coaching excellence (pp. 3-12, 2nd edition). New York, NY: Palgrave Macmillan.

Ting, S. (2006). Our view of coaching for leadership development. In S. Ting, \& P. Sisco (Eds.). The CCL handbook of coaching: A guide for leader coach (pp.15- 33). San Francisco, CA: Jossey Bass: A Wiley Imprint.

Uhl-Bien, M. (2006). Relational leadership theory: Exploring the social processes of leadership and organizing. The Leadership Quarterly 17(6), 654-676.

Uhl-Bien, M., Maslyn, J., \& Ospina, S. (2012). The nature of relational leadership. In D.V. Day, \& J. Antonakis (Eds.), The nature of leadership (pp. 289-330). Thousand Oaks, CA: Sage Publications.

\section{Author Contact}

Ken Otter, Ph.D.

Co-Director, The Leadership Center

Saint Mary's College of California

1928 St. Mary's Rd. Moraga, CA 94575

email: kotter@stmarys-ca.edu 